\title{
Bacterial Manipulation of Autophagic Responses in Infection and Inflammation
}

Yang Jiao and Jun Sun*

Division of Gastroenterology and Hepatology, College of Medicine, University of Illinois at Chicago, Chicago, IL, United States

Eukaryotes have cell-autonomous defenses against environmental stress and pathogens. Autophagy is one of the main cellular defenses against intracellular bacteria. In turn, bacteria employ diverse mechanisms to interfere with autophagy initiation and progression to avoid elimination and even to subvert autophagy for their benefit. This review aims to discuss recent findings regarding the autophagic responses regulated by bacterial effectors. Effectors manipulate autophagy at different stages by using versatile strategies, such as interfering with autophagy-initiating signaling, preventing the recognition of autophagy-involved proteins, subverting autophagy component homeostasis, manipulating the autophagy process, and impacting other biological processes. We describe the barriers for intracellular bacteria in host cells and highlight the role of autophagy in the host-microbial interactions. Understanding the mechanisms through which bacterial effectors manipulate host responses will provide new insights into therapeutic approaches for prevention and treatment of chronic inflammation and infectious diseases.

Keywords: autophagy, effectors, bacteria, LC-3, innate immunity, microbiome

\section{INTRODUCTION}

Autophagy, which literally means "self-eating," is an intrinsic process of eukaryotes that delivers cytoplasmic material to lysosomes for degradation. During this process, cytoplasmic material is enclosed by phagophores. Then, the phagophores elongate to form autophagosomes that fuse with lysosomes to form autolysosomes where the cargoes are degraded (1). Autophagy is an important biological process that is involved in immune responses, embryonic development, cell death, and cellular defense (2). It is important for host responding to nutrient stress as well as eliminating intracellular pathogens. Better understanding of autophagy mechanism will allow us to develop therapeutic drugs, vaccines, and host-directed strategies for successful control of intracellular microorganisms.

There are three forms of autophagy that are commonly described: chaperone-mediated autophagy (CMA), microautophagy, and macroautophagy. Macroautophagy is then divided into non-selective and selective autophagy. Various cargoes, such as defective mitochondria, defective endoplasmic reticulum (ER), lipids, and foreign organisms, are targeted by selective autophagy for degradation. When autophagy engulfs microorganisms for clearance, this pathway is called "xenophagy," which plays a central role in cellular defense (3).

To survive in host cells, bacteria employ multiple mechanisms to protect against cellular defenses. Effectors, one type of weapons used by bacteria, are proteins translocated from the bacterial cytoplasm to the host cell cytoplasm by a series of secretion systems (T1SS-T8SS) (4). 
Bacterial effectors have the capacity to influence host cellular biological processes, including signaling pathways, tight junctions, phagocytosis, apoptosis, and autophagy $(5,6)$.

This review will discuss the recent research advancement ( $<6$ years) in interactions between bacterial effectors and host autophagic responses. We synoptically describe the barriers for intracellular bacteria in host cells and highlight the role of autophagy in these processes. Furthermore, we emphasize the different strategies used by bacterial effectors from secretion systems (T3SS, T44SS, T6SS, and T7SS) to manipulate autophagic responses in host cells in infection and inflammation.

\section{THE FATE OF INTRACELLULAR BACTERIA IN AUTOPHAGY}

There is a constant battle between bacterial evasion mechanisms and host cellular defenses, and the fate of intracellular bacteria is determined by the outcome of this battle. Intracellular pathogens can be internalized by either phagocytic or nonphagocytic cells. After entry into host cells, bacteria are localized to internalization vacuoles, which are designated as phagosomes (Figure 1). To survive, bacterial effectors have different strategies to interfere with host, including affecting autophagy-initiating signaling, modifying LC3 protein, avoiding autophagosome-lysosome fusion, affecting lysosome function, deubiquitinating ubiquitinated substrate around intracellular bacteria, etc. Therefore, intracellular bacteria obtain nutrients to replicate or hide to wait for opportunities.

Pathogen-containing phagosomes fuse with lysosomes via phagocytosis to form phagolysosomes, where the bacteria are eliminated. Notably, recent reports have described a process called LC3-associated phagocytosis (LAP) that recruits the autophagy marker protein LC3 to pathogencontaining phagosomes, and the subsequent fusion of these phagosomes with lysosomes results in pathogen digestion (7). To prevent phagocytosis-mediated bacterial killing, bacteria can either modify the phagosomes to form pathogen-containing vacuoles, thus avoiding fusion with lysosomes (Mycobacterium tuberculosis), or disrupt the vacuoles to escape from the phagosomes (Salmonella Typhimurium) (8). Xenophagy plays a key role in cell resistance to these crafty bacteria by clearing pathogen-containing vacuoles, escaped pathogens, damaged vacuoles and pathogen-containing phagosomes. Pathogens have many unique ways to escape or subvert host xenophagy. These mechanisms are complex and fall outside the scope of this article; readers are referred to more comprehensive reviews of this subject $(9,10)$. Here, we focus on the effectors employed by Gram-negative bacteria to disrupt the autophagic responses of host cells.

\footnotetext{
Abbreviations: ATG protein, Autophagy-related protein; CCVs, Coxiellacontaining vacuoles; DCs, Dendritic cells; ER, endoplasmic reticulum; JNK, cJun N-terminal kinase; LAP, LC3-associated phagocytosis; LUBAC, liner ubiquitin chain assembly complex; RAB proteins, the ras superfamily G-proteins; SCVs, Salmonella-containing vacuoles; SPI, Salmonella pathogenicity island; T3SS, type III secretion system; T4SS, type IV secretion system; T6SS, type VI secretion system; T7SS, type VII secretion system.
}

\section{THE AUTOPHAGY MANIPULATION STRATEGIES OF T3SS EFFECTORS}

Bacteria can be eliminated by autophagy, thus, Gram-negative bacteria use T3SS effectors to suppress or subvert this process. We summarized all related research work in Table $\mathbf{1}$ and discussed the recent progress ( $<6$ years) of different strategies bacteria used, e.g., interference with signaling or ATG proteins, prevention of recognition by autophagy mechanisms, subversion of autophagic components for bacterial survival, and escape from LC3-associated phagocytosis.

\section{Interference With Signaling or ATG Proteins Involved in Autophagy}

Shigella flexneri effector IcsB, was recently found to repress the early recruitment of LC3 during infection (11). During early infection $(40 \mathrm{~min}$ ), IcsB recruits the host protein Toca1 to intracellular $S$. flexneri to suppress the recruitment of LC3 and NDP52 around these intracellular bacteria. LC3 is a marker of autophagosomes, it is also present in LC3associated phagocytosis. Therefore, this research suggests that IcsB manipulates Toca-1 to inhibit LC3-associated phagocytosis and/or LC3 recruitment to vacuolar membrane remnants early during infection (11). However, this study lacks supporting morphological observations.

In macrophages, SPI-2 (Salmonella pathogenicity island2) T3SS is responsible for suppressing autophagy by actively manipulating the recruitment of focal adhesion kinase (FAK) to Salmonella-containing vacuoles (SCVs) and then stimulating the Akt-mTORC1 signaling pathway. However, the effector(s) that are responsible for this process remain unclear (12). Furthermore, the effector AWR5 from the plant pathogen Ralstonia solanacearum can also affect the mTOR signaling pathway to activate autophagy (13). Research indicates that AWR5, which is expressed heterologously in yeast, induces growth inhibition and autophagic flux. AWR5 may exert its function by inhibiting TORC1 upstream of PP2A directly or indirectly and thus promoting autophagy.

The effector SseF and SseG secreted by Salmonella Typhimurium can inhibit autophagy in host cells by the same autophagy blockade (14). Mechanistically, SseF and SseG impair autophagy initiation by directly interacting with the small GTPase Rab1A in the host cell. And the disruption of Rab1A signaling blocked the recruitment and activation of Unc51-like autophagy-activating kinase 1 (ULK1) and decreased phosphatidylinositol 3-phosphate biogenesis, which ultimately suppress autophagosome formation.

Salmonella T3SS effector SopF was found to be a general xenophagy inhibitor without affecting canonical autophagy. Using Salmonella Typhimurium $\Delta s o p F$, the researchers identified the V-ATPase-ATG16L1 axis that mediates xenophagy initiation in HeLa cells. And SopF can target ATP6V0C for ADP-ribosylation on Gln124, thereby blocking bacterial autophagy and infection-induced recruitment of ATG16L1 by the V-ATPase (15). 


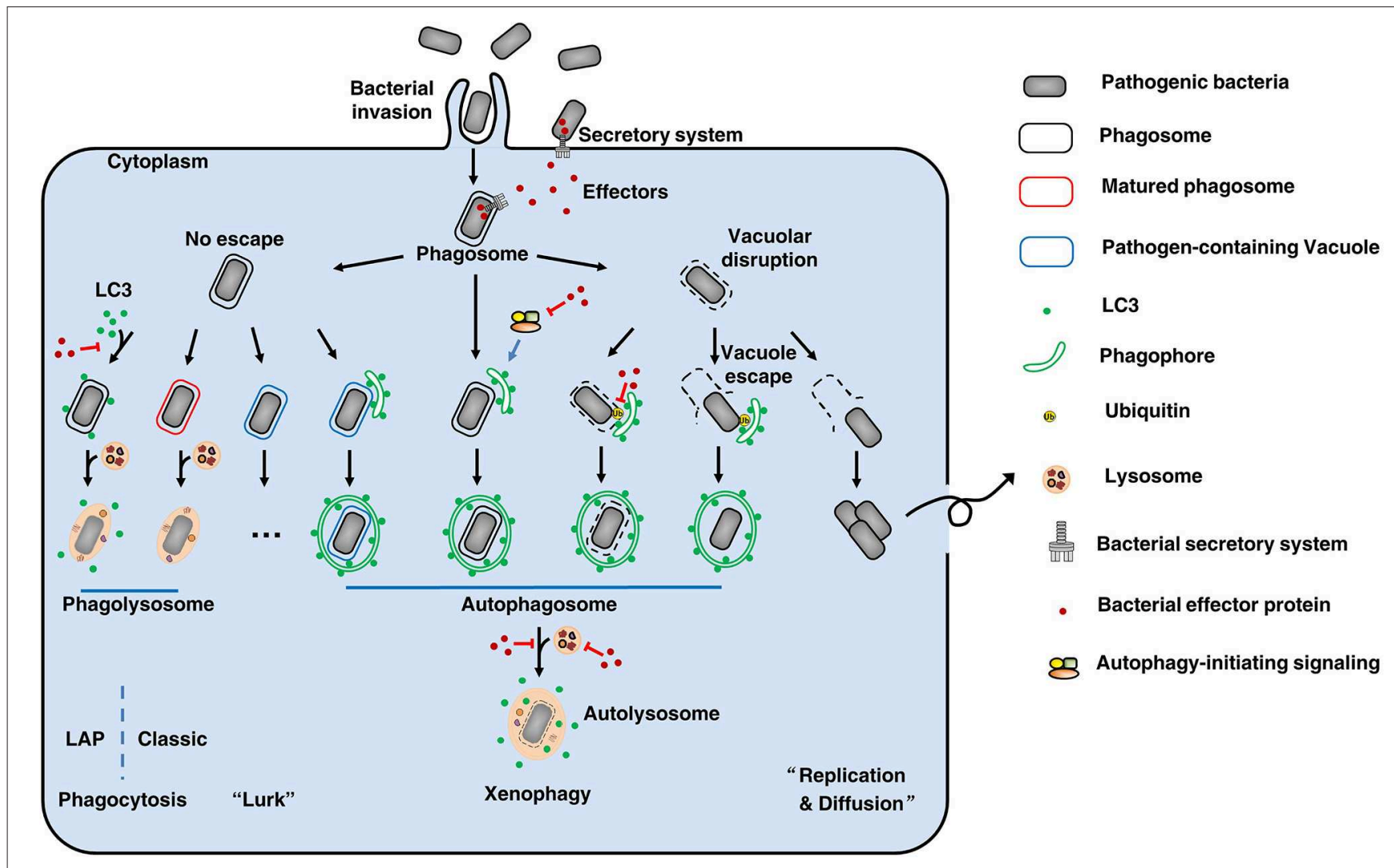

FIGURE 1 | The fate of intracellular bacteria. After entry into host cells, bacteria are localized to internalization vacuoles, which are designated as phagosomes To survive, bacteria employ diverse means to escape or subvert host cellular defenses, especially using its secretion systems and effectors. By various ways, some bacteria (like Salmonella Typhimurium) can damage the phagosomes and then escape to the cytoplasm, where can obtain nutrients to replicate and to diffuse. On the other hand, to clean up the bacteria remaining in phagosomes, the phagosomes will be mature and fuse with lysosomes to form phagolysosomes where the bacteria are degraded. This's the classic phagocytosis. To prevent phagocytosis-mediated bacterial killing, bacteria (such as Mycobacterium tuberculosis) can modify the phagosomes to form pathogen-containing vacuoles, thus avoiding fusion with lysosomes. These bacteria will lurk to wait for opportunities for their survival. Therefore, xenophagy plays a key role in cell resistance to these crafty bacteria by clearing pathogen-containing vacuoles, escaped pathogens, damaged vacuoles, and pathogen-containing phagosomes. During this process, above targets are enclosed by phagophores. Then, the phagophores elongate to form autophagosomes that fuse with lysosomes to form autolysosomes where the bacteria are eliminated. Notably, LC3-associated phagocytosis (LAP) can recruit the autophagy marker protein LC3 to pathogen-containing phagosomes, and the subsequent fusion of these phagosomes with lysosomes results in pathogen digestion. Additionally, there are other unmentioned cross-talk between xenophagy and phagocytosis. Back to our theme, effectors-autophagy interactions. Using effectors delivered by secretion systems, bacteria are able to interfere with autophagy-initiating signaling, modify LC3 protein, avoid autophagosome-lysosome fusion, affect lysosome function, and deubiquitinate ubiquitinated substrate around intracellular bacteria, etc. Thus, bacteria can suppress or subvert autophagic responses for their survival. Overall, there is a constant battle between bacterial evasion mechanisms and host cellular defenses, and the fate of intracellular bacteria is determined by the outcome of this battle.

We recently show that Salmonella Enteritidis effector AvrA can suppress autophagy (16). The AvrA protein is an effector that possesses acetyltransferase and deubiquitinase activity and inhibits the host c-Jun N-terminal kinase (JNK)/AP-1 and NF$\kappa \mathrm{B}$ signaling pathways; thus, AvrA inhibits host inflammatory responses and stabilizes intestinal tight junctions to the benefit of Salmonella survival $(31,32)$. We found that AvrA can inhibit autophagic responses by decreasing Beclin-1 protein levels, and this process occurs via JNK/c-Jun/AP-1 signaling pathway inhibition.

\section{Prevention of Recognition by Autophagy Mechanisms}

Bacterial T3SS effectors can interfere with autophagy recognition mechanisms, thus avoiding bacterial killing in the host. IcsB from $S$. flexneri is one of the best-known effectors with this capability. IcsB competes with ATG5 binding to VirG (a bacterial surface protein), thereby masking the bacteria from recognition by autophagy mechanisms. Therefore, IcsB mutants are targeted for autophagy during multiplication in host cells infected with S. flexneri (18). Taken together, it suggests that the S. flexneri effector IcsB modulates LC3 recruitment around intracellular bacteria at the early stage of infection and inhibits autophagy late during infection $(11,18)$.

The S. flexneri T3SS effector IpaH1.4 is another example of preventing recognition by autophagy mechanisms (19). The E3 ligase LUBAC (liner ubiquitin chain assembly complex) can generate linear (M1-linked) polyubiquitin patches in the ubiquitin coat of intracellular bacteria, which recruit Optineurin and Nemo for xenophagy. In contrast, the effector protein IpaH1.4, a bacterial secreted E3 ubiquitin ligase 30, antagonizes the LUBAC-mediated accumulation of M1-linked ubiquitin 
TABLE 1 | Strategies used by T3SS effectors to manipulate autophagy.

\begin{tabular}{|c|c|c|c|c|c|}
\hline Bacteria & Effectors & Host model & Description & Bacterial survival & References \\
\hline \multicolumn{6}{|c|}{ Interfering with signaling or proteins involved in autophagy } \\
\hline Shigella flexneri & $\operatorname{lcsB}$ & $\begin{array}{l}\text { HeLa cells, 293T } \\
\text { cells and MEFs }\end{array}$ & $\begin{array}{l}\text { Recruits the host protein Toca-1 to } \\
\text { repress the recruitment of LC3 } \\
\text { around these intracellular bacteria }\end{array}$ & $\begin{array}{l}\text { The absence of IcsB has no effect on } \\
\text { bacterial survival up to } 3 \mathrm{~h} \text { of infection }\end{array}$ & $(11)$ \\
\hline $\begin{array}{l}\text { Salmonella } \\
\text { Typhimurium }\end{array}$ & Unknown & $\begin{array}{l}\text { Mouse peritoneal } \\
\text { macrophages }\end{array}$ & $\begin{array}{l}\text { Recruits FAK to SCVs and then } \\
\text { stimulates the Akt-mTORC1 signaling } \\
\text { pathway }\end{array}$ & $\begin{array}{l}\text { In FAK-deficient macrophages, } \\
\text { Akt/mTOR signaling is attenuated and } \\
\text { autophagic capture of intracellular } \\
\text { bacteria is enhanced, resulting in } \\
\text { reduced bacterial survival }\end{array}$ & $(12)$ \\
\hline $\begin{array}{l}\text { Ralstonia } \\
\text { solanacearum }\end{array}$ & AWR5 & $\begin{array}{l}\text { Yeast, } \\
\text { N. benthamiana }\end{array}$ & $\begin{array}{l}\text { Suppresses TOR signaling by } \\
\text { inhibiting TORC1 upstream of PP2A }\end{array}$ & Not applicable & $(13)$ \\
\hline $\begin{array}{l}\text { Salmonella } \\
\text { Typhimurium }\end{array}$ & $\begin{array}{l}\text { SseF and } \\
\text { SseG }\end{array}$ & $\begin{array}{l}\text { HeLa cells, } \\
\text { Rab1A }{ }^{-/-} \\
\text {RAW264.7 cell, } \\
\text { Rab1A }{ }^{-/-} \text {mouse }\end{array}$ & Inhibits Rab1A-mediated autophagy & $\begin{array}{l}\text { SseF or SseG-deficient bacterial } \\
\text { strains exhibit reduced survival and } \\
\text { growth in both mammalian cell lines } \\
\text { and mouse infection models }\end{array}$ & $(14)$ \\
\hline $\begin{array}{l}\text { Salmonella } \\
\text { Typhimurium }\end{array}$ & SopF & HeLa cells & $\begin{array}{l}\text { Targets ATP6V0C for } \\
\text { ADP-ribosylation on GIn124, thereby } \\
\text { blocking recruitment of ATG16L1 by } \\
\text { the V-ATPase }\end{array}$ & $\begin{array}{l}\Delta \text { sopF grow less efficiently in HeLa } \\
\text { cells than the WT strain. And this } \\
\text { SopF-dependent replication was } \\
\text { diminished in ATG16L1-/- cells, } \\
\text { which were rescued by ATG16L1 }\end{array}$ & $(15)$ \\
\hline $\begin{array}{l}\text { Salmonella } \\
\text { Enteritidis }\end{array}$ & AvrA & $\begin{array}{l}\text { HCT116 cells, } \\
\text { organoids and } \\
\text { mice }\end{array}$ & $\begin{array}{l}\text { Reduces the protein expression of } \\
\text { Beclin-1 by inhibiting the } \\
\text { JNK/c-Jun/AP-1 signaling pathway }\end{array}$ & $\begin{array}{l}\text { AvrA-deficient bacterial strains } \\
\text { colonized human epithelial cells show } \\
\text { a decreased intracellular bacterial } \\
\text { load compared to those colonized } \\
\text { with wild type }\end{array}$ & $(16)$ \\
\hline $\begin{array}{l}\text { Burkholderia } \\
\text { pseudomallei }\end{array}$ & $\begin{array}{l}\text { TTSS1 } \\
\text { ATPase }\end{array}$ & RAW 264.7 cells & $\begin{array}{l}\text { Decreases colocalization with LC3 } \\
\text { but does not affect autophagy }\end{array}$ & $\begin{array}{l}\text { TTSS1 ATPase-deficient bacterial } \\
\text { strains has diminished survival and } \\
\text { replicative capacity in RAW264.7 cells }\end{array}$ & $(17)$ \\
\hline \multicolumn{6}{|c|}{ Preventing recognition by autophagy mechanisms } \\
\hline Shigella flexneri & $\operatorname{lcsB}$ & $\begin{array}{l}\text { BHK cells, MDCK } \\
\text { cells and atg5 } \\
\text { MEFs }\end{array}$ & $\begin{array}{l}\text { Competes with ATG5 binding to the } \\
\text { bacterial surface protein VirG }\end{array}$ & $\begin{array}{l}\text { The absence of IcsB has no effect on } \\
\text { bacterial survival up to } 3 \mathrm{~h} \text { of infection }\end{array}$ & $(18)$ \\
\hline Shigella flexneri & IpaH1.4 & MEFs & $\begin{array}{l}\text { Antagonizing the LUBAC-mediated } \\
\text { accumulation of M1-linked ubiquitin } \\
\text { chains on bacterial surfaces, as well } \\
\text { as the recruitment of Optineurin and } \\
\text { Nemo }\end{array}$ & Not applicable & (19) \\
\hline $\begin{array}{l}\text { Salmonella } \\
\text { Typhimurium }\end{array}$ & SseL & $\begin{array}{l}\text { HeLa cells, } \\
\text { RAW264.7 cells } \\
\text { and BMM }\end{array}$ & $\begin{array}{l}\text { Splits cytosolic aggregates around } \\
\text { SCVs by its deubiquitinating activity }\end{array}$ & $\begin{array}{l}\text { SseL contributes to bacterial } \\
\text { replication in restrictive cellular } \\
\text { environment }\end{array}$ & $(20)$ \\
\hline \multicolumn{6}{|c|}{ Subverting autophagic components for bacterial survival } \\
\hline $\begin{array}{l}\text { Vibrio } \\
\text { parahaemolyticus }\end{array}$ & VopQ & HeLa cells & $\begin{array}{l}\text { Forms a gated ion channel on } \\
\text { lysosomes }\end{array}$ & $\begin{array}{l}\text { VopQ attenuates phagocytosis of } \\
\text { Vibrio parahaemolyticus during } \\
\text { infection }\end{array}$ & $(21-23)$ \\
\hline $\begin{array}{l}\text { Salmonella } \\
\text { Typhimurium }\end{array}$ & SopB & HeLa cells & $\begin{array}{l}\text { Increases the interaction of } \\
\text { Salmonella with autophagosomes }\end{array}$ & $\begin{array}{l}\text { Autophagy facilitates Salmonella } \\
\text { replication in the cytosol of HeLa cells }\end{array}$ & $(24)$ \\
\hline \multicolumn{6}{|c|}{ Affecting autophagy by subverting host cell homeostasis } \\
\hline $\begin{array}{l}\text { Salmonella } \\
\text { Typhimurium }\end{array}$ & SipB & BMDPM & $\begin{array}{l}\text { Disrupts mitochondria to induce } \\
\text { autophagy }\end{array}$ & Not applicable & $(25)$ \\
\hline Shigella flexneri & IcsB & MDAMC cells & $\begin{array}{l}\text { Interacts with host cholesterol to } \\
\text { evade autophagy }\end{array}$ & $\begin{array}{l}\text { The absence of IcsB has no effect on } \\
\text { bacterial survival up to } 3 \mathrm{~h} \text { of infection }\end{array}$ & (26) \\
\hline $\begin{array}{l}\text { Burkholderia } \\
\text { pseudomallei }\end{array}$ & BopA & $\begin{array}{l}\text { RAW } 264.7 \text { cells, } \\
\text { MEFs, MDAMC } \\
\text { cells }\end{array}$ & $\begin{array}{l}\text { Interacts with host cholesterol to } \\
\text { evade autophagy }\end{array}$ & Not applicable & $(26,27)$ \\
\hline \multicolumn{6}{|c|}{ Manipulating autophagy via unknown mechanisms } \\
\hline Vibrio alginolyticus & Unknown & $\begin{array}{l}\text { Several } \\
\text { mammalian cell } \\
\text { lines }\end{array}$ & $\begin{array}{l}\text { Activates autophagy via unknown } \\
\text { mechanisms }\end{array}$ & Not applicable & $(28)$ \\
\hline
\end{tabular}


TABLE 1 | Continued

\begin{tabular}{|c|c|c|c|c|c|}
\hline Bacteria & Effectors & Host model & Description & Bacterial survival & References \\
\hline $\begin{array}{l}\text { Pseudomonas } \\
\text { aeruginosa }\end{array}$ & Unknown & $\begin{array}{l}\text { AEC line (A549 } \\
\text { cells) }\end{array}$ & Unknown & Not applicable & (29) \\
\hline $\begin{array}{l}\text { Yersinia } \\
\text { enterocolitica }\end{array}$ & Unknown & $\begin{array}{l}\text { Murine J774A.1 } \\
\text { macrophages }\end{array}$ & $\begin{array}{l}\text { Suppresses autophagy via unknown } \\
\text { mechanisms }\end{array}$ & Not applicable & (30) \\
\hline \multicolumn{6}{|c|}{ Escaping LC3-associated phagocytosis } \\
\hline Shigella flexneri & IcsB & $\begin{array}{l}\text { HeLa cells, 293T } \\
\text { cells and MEFs }\end{array}$ & $\begin{array}{l}\text { Recruits the host protein Toca- } 1 \text { to } \\
\text { repress LC3 recruitment around these } \\
\text { intracellular bacteria }\end{array}$ & $\begin{array}{l}\text { The absence of IcsB has no effect on } \\
\text { bacterial survival up to } 3 \mathrm{~h} \text { of infection }\end{array}$ & (11) \\
\hline $\begin{array}{l}\text { Burkholderia } \\
\text { pseudomallei }\end{array}$ & BopA & RAW264.7 cells & $\begin{array}{l}\text { Represses LC3 and LAMP1 } \\
\text { recruitment via an unknown } \\
\text { mechanism }\end{array}$ & $\begin{array}{l}\text { bopA mutant bacteria show reduced } \\
\text { intracellular survival }\end{array}$ & (7) \\
\hline
\end{tabular}

chains on bacterial surfaces, as well as the recruitment of Optineurin and Nemo. Therefore, S. flexneri profoundly cripples LUBAC-dependent cellular defense mechanisms-xenophagy.

\section{Subversion of Autophagic Components for Bacterial Survival}

T3SS effectors interact with autophagic components to interrupt autophagy. Vibrio parahaemolyticus VopQ is an effector that affects lysosomes. VopQ forms a gated ion channel in lysosomes to cause deacidification, thus disturbing autophagic flux. Moreover, VopQ binds directly to the V-ATPase $\mathrm{V}_{\mathrm{o}}$ domain of lysosomes to block autophagosome-lysosome fusion (21-23).

It has been reported that Salmonella requires the RAB1 (the ras superfamily G-proteins-1)-mediated autophagy pathway for its survival (33). Salmonella Typhimurium SopB regulate this process to increases the interaction of Salmonella with autophagosomes for replication in HeLa cells. One possible reason for this finding is that SopB ubiquitination promotes the association of Salmonella and autophagosomes (24). Nevertheless, the detailed mechanism is still unclear.

\section{Escape From LC3-Associated Phagocytosis}

LAP is not a member of the autophagy pathway. However, the autophagy marker LC3 protein participates in this process, which makes it hard to be ignored. We should distinguish autophagy from LAP in research work. For instance, effector IcsB, which may manipulate Toca-1 to inhibit LAP (11). The T3SS effector BopA also plays a role in preventing bacterial killing via LAP. Because the BopA mutants showed higher levels of colocalization with LC3 and the lysosomal marker LAMP1, suggesting enhanced elimination through LAP (7).

\section{MANIPULATING AUTOPHAGY VIA BACTERIAL EFFECTORS FROM OTHER SECRETION SYSTEMS}

The effectors from other secretion systems of Gram-negative bacteria possess approaches for manipulating autophagy, as summarized in Table 2 and discussed in the following text (papers within 6 years).

\section{Interference With Signaling or ATG Proteins Involved in Autophagy}

RavZ, is delivered by T4SS from Legionella pneumophila. RavZ can inhibit autophagy in HEK293 cells infected with L. pneumophila $(34,35)$. This protein uses its LIR motifs to bind to the LC3 protein and then extract LC3-PE (LC3- phosphatidylethanolamine) from the membrane of autophagosomes (35). RavZ hydrolyzes the amide bonds between glycine residues and aromatic residues at the carboxyl-terminal of the LC3 protein, using a catalytic mechanism similar to that of the Atg4. Thus, modified LC3 cannot be reconjugated by Atg7 and Atg3 in the process of autophagosome formation.

The protein VgrG2 from VpT6SS2 (T6SS-2 of Vibrio parahaemolyticus) induces autophagy by targeting the initial events of autophagic signaling (37). VgrG2 is a translocon of VpT6SS2. Heterogenous expression of VgrG2 increases LC3-II lipidation in macrophage cells and increases the accumulation of LC3-II in RAW264.7 cells treated with chloroquine (an inhibitor of autophagosome-lysosome fusion). Furthermore, VgrG2 mutants decrease the level of intracellular cAMP, which is necessary for the activation of the PRKA-AMPK-SIRT1 signaling pathway to induce autophagy in HUVECs treated with resveratrol (47). This finding suggests the possible role of targeting cAMP signaling in the VgrG2-mediated induction of autophagic responses (37).

A recent report has shown that Ehrlichia chaffeensis acquires nutrients from host cells by inducing RAB5-regulated autophagy via its T4SS-delivered effector Etf-1(6). Etf-1 interacts with RAB5, Beclin-1, VPS34, and autophagy-initiating PtdIns3K and is targeted to ehrlichial inclusions; through these mechanisms, Etf-1 induces autophagy to deliver host cytosolic nutrients for its replication while avoiding autophagic clearance (6).

\section{Prevention of Recognition by Autophagy Mechanisms}

Bartonella quintana T4SS effector BepE was identified to induce selective autophagy. The researchers found that ectopic expression of BepE specifically induced punctate structures that colocalized with LC3-II in host cells. Further study showed that host cells utilize selective autophagy to confine and degrade BepE via poly-ubiquitin chain of K63 linkage conjugation (38). 
TABLE 2 | Strategies used by the effectors from T4SS, T6SS, and T7SS to manipulate autophagy.

\begin{tabular}{|c|c|c|c|c|c|}
\hline Bacteria & Effectors & Host model & Description & Bacterial survival & References \\
\hline \multicolumn{6}{|c|}{ Interfering with signaling or proteins involved in autophagy } \\
\hline $\begin{array}{l}\text { Legionella } \\
\text { pneumophila }\end{array}$ & $\begin{array}{l}\text { RavZ } \\
\text { (T4SS) }\end{array}$ & $\begin{array}{l}\text { HEK293 cells and } \\
\text { MCF- } 7 \text { cells }\end{array}$ & $\begin{array}{l}\text { Cleaving LC3 off the membrane and } \\
\text { modifying LC3 by its de-conjugating } \\
\text { enzyme activity }\end{array}$ & Not applicable & $(34,35)$ \\
\hline $\begin{array}{l}\text { Anaplasma } \\
\text { phagocytophilum }\end{array}$ & $\begin{array}{l}\text { Ats-1 } \\
\text { (T4SS) }\end{array}$ & $\begin{array}{l}\text { THP }-1 \text { cells, } \\
\text { RF/6A cells and } \\
\text { Beclin- } 1^{+/-} \text {mice }\end{array}$ & $\begin{array}{l}\text { Binds host Beclin-1 protein and hijacks } \\
\text { Beclin-1-Atg14L autophagy initiation }\end{array}$ & Not applicable & $(36)$ \\
\hline $\begin{array}{l}\text { Vibrio } \\
\text { parahaemolyticus }\end{array}$ & $\begin{array}{l}\text { VgrG2 } \\
\text { (T6SS) }\end{array}$ & RAW264.7 cells & $\begin{array}{l}\text { Possibly reduces the level of intracellular } \\
\text { CAMP }\end{array}$ & Not applicable & $(37)$ \\
\hline $\begin{array}{l}\text { Ehrlichia } \\
\text { chaffeensis }\end{array}$ & $\begin{array}{l}\text { Etf-1 } \\
\text { (T4SS) }\end{array}$ & $\begin{array}{l}\text { THP-1 cells, } \\
\text { HEK } 293 \text { cells and } \\
\text { DH82 cells }\end{array}$ & $\begin{array}{l}\text { Targets host RAB5, Beclin-1, VPS34, and } \\
\text { autophagy - initiating Ptdlns3K to ehrlichial } \\
\text { inclusions to induce autophagy }\end{array}$ & $\begin{array}{l}\text { Ehrlichia chaffeensis proliferation } \\
\text { requires class III Ptdlns } 3 \mathrm{~K} \text { activation } \\
\text { and } \mathrm{BECN1} \text {, and is enhanced by } \\
\text { induction of autophagy with } \\
\text { rapamycin }\end{array}$ & (6) \\
\hline \multicolumn{6}{|c|}{ Preventing recognition by autophagy mechanisms } \\
\hline $\begin{array}{l}\text { Bartonella } \\
\text { quintana }\end{array}$ & $\begin{array}{l}\text { BepE } \\
\text { (T4SS) }\end{array}$ & $\begin{array}{l}\text { HeLa cells, } \\
\text { HEK293 cells and } \\
\text { HUVECs }\end{array}$ & $\begin{array}{l}\text { Induces selective autophagy by } \\
\text { conjugation with K63 poly-ubiquitin chain }\end{array}$ & $\begin{array}{l}\text { Not applicable (But cells with } \\
\text { BepE-induced autophagy are about } \\
\text { 3-fold more effective at engulfing } \\
\text { Bartonella quintana than cells with } \\
\text { BepE-induced filopodia and } \\
\text { membrane ruffles) }\end{array}$ & $(38)$ \\
\hline \multicolumn{6}{|c|}{ Subverting autophagic components for bacterial survival } \\
\hline $\begin{array}{l}\text { Legionella } \\
\text { pneumophila }\end{array}$ & $\begin{array}{l}\text { DrrA, LidA, } \\
\text { RalF and } \\
\text { LepB } \\
\text { (T4SS) }\end{array}$ & $\begin{array}{l}\text { Primary mouse } \\
\text { macrophages }\end{array}$ & $\begin{array}{l}\text { Interacts with RAB proteins to manipulate } \\
\text { autophagosomal maturation }\end{array}$ & Not applicable & (39) \\
\hline Coxiella burnetii & $\begin{array}{l}\text { Cig2 } \\
\text { (T4SS) }\end{array}$ & HeLa cells & $\begin{array}{l}\text { Promotes the fusion of Coxiella-containing } \\
\text { vacuoles with autophagosomes to } \\
\text { maintain this vacuole in an autolysosomal } \\
\text { stage of maturation }\end{array}$ & $\begin{array}{l}\text { Coxiella burnetii is highly resistant to } \\
\text { environmental stresses and is able to } \\
\text { replicate in acidified lysosome-derived } \\
\text { vacuoles }\end{array}$ & $(40)$ \\
\hline $\begin{array}{l}\text { Mycobacterium } \\
\text { tuberculosis (Note: } \\
\text { this strain is not } \\
\text { suitable for using } \\
\text { Gram stain) }\end{array}$ & $\begin{array}{l}\text { ESAT-6 } \\
\text { (T7SS) }\end{array}$ & $\begin{array}{l}\text { Human primary } \\
\text { DCs }\end{array}$ & Impairs autophagosome-lysosome fusion & Not applicable & $(41)$ \\
\hline \multicolumn{6}{|c|}{ Mediating autophagy by subverting host cell homeostasis } \\
\hline $\begin{array}{l}\text { Legionella } \\
\text { pneumophila }\end{array}$ & $\begin{array}{l}\text { LpSpl } \\
\text { (T4SS) }\end{array}$ & $\begin{array}{l}\text { HEK-293T cells } \\
\text { and THP-1 } \\
\text { macrophages }\end{array}$ & $\begin{array}{l}\text { Inhibits autophagy by disrupting host } \\
\text { sphingolipid biosynthesis }\end{array}$ & Not applicable & $(42)$ \\
\hline $\begin{array}{l}\text { Pseudomonas } \\
\text { aeruginosa }\end{array}$ & $\begin{array}{l}\text { TplE } \\
\text { (T6SS) }\end{array}$ & $\begin{array}{l}\text { HeLa cells and } \\
\text { HEK293T cells }\end{array}$ & $\begin{array}{l}\text { Activates autophagy responses by } \\
\text { subverting ER homeostasis }\end{array}$ & $\begin{array}{l}\text { In intra- and inter-species competition } \\
\text { studies show that the loss of tplE } \\
\text { gave rise to a growth advantage of } \\
\text { the recipient strain }\end{array}$ & $(43)$ \\
\hline \multicolumn{6}{|c|}{ Manipulating autophagy via unknown mechanisms } \\
\hline Brucella & $\begin{array}{l}\text { VceA } \\
\text { (T4SS) }\end{array}$ & HPT-8 cells & $\begin{array}{l}\text { Suppresses autophagy via unknown } \\
\text { mechanisms }\end{array}$ & Not applicable & $(44)$ \\
\hline \multicolumn{6}{|c|}{ Escaping LC3-associated phagocytosis } \\
\hline Legionella species & $\begin{array}{l}\text { RavZ } \\
\text { (T4SS) }\end{array}$ & $\begin{array}{l}\text { HEK } 293 \text { cells and } \\
\text { MCF- } 7 \text { cells }\end{array}$ & $\begin{array}{l}\text { Cleaving LC3 off the membrane and } \\
\text { modifying LC3 by its de-conjugating } \\
\text { enzyme activity }\end{array}$ & Not applicable & $(34,45)$ \\
\hline $\begin{array}{l}\text { Legionella } \\
\text { pneumophila }\end{array}$ & $\begin{array}{l}\text { LpSpl } \\
\text { (T4SS) }\end{array}$ & & May be responsible for inhibiting LAP & Not applicable & $(42,46)$ \\
\hline
\end{tabular}

\section{Subversion of Autophagic Components for Bacterial Survival}

The Coxiella burnetii protein Cig2 is a T4SS effector that hijacks host autophagosomes. Coxiella burnetii is highly resistant to environmental stresses and is able to replicate in acidified lysosome-derived vacuoles. Coxiella-containing vacuoles (CCVs) are highly fusogenic with each other and with other organelles of the endocytic pathway; therefore, good-sized vacuole formation is promoted (48). The effector Cig2 can promote the fusion of CCVs with autophagosomes to maintain these vacuoles in 
an autolysosomal stage of maturation, thus promoting CCV homotypic fusion and influencing host infection tolerance in a moth model (40).

\section{Mediating Autophagy by Subverting Host Cell Homeostasis}

A T4SS effector and a T6SS effector have been confirmed to affect autophagy by regulating other biological processes. The protein $L p S p l$ is translocated by the T4SS of L. pneumophila. LpSpl has a high degree of similarity to eukaryotic sphingosine-1 phosphate lyase. Interestingly, cells infected with $L p S p l$ mutants have significantly greater LC3 recruitment than WT-infected cells, suggesting that $L p S p l$ is responsible for suppressing autophagy during infection. Together, these data indicate that $L p S p l$ inhibits autophagy by disrupting host sphingolipid biosynthesis. However, the complete mechanism has not been elucidated (42).

T6SS effector TplE from Pseudomonas aeruginosa is a Tle4 phospholipase family protein that possesses inter-bacterial killing capacity (49). Noteworthy, TplE targets and disrupts the host ER (endoplasmic reticulum) via its eukaryotic PGAP1-like domain. ER homeostasis perturbation can lead to the activation of the unfolded protein response, which acts as a potent trigger of autophagy (50). Therefore, TplE activates autophagy responses by subverting ER homeostasis (43).

\section{Manipulating Autophagy via Unknown Mechanisms}

Effector VceA from Brucella T4SS is involved in host autophagic responses (44). As The Atg5, LC3-II, and Bcl-2 mRNA expression were significantly increased in the VceA mutant than the WT group. However, this study lacks the sufficient determining of autophagy process and the mechanism is still unclear.

\section{Escape From LC3-Associated Phagocytosis}

T4SS of Legionella species has been reported to play a role in suppressing LAP (46). The T4SS effector RavZ from L. pneumophila strains can inhibit LAP via its capability to irreversibly deconjugate LC3, which has been previously described $(34,45)$. However, this LAP escape is not due solely to the effector RavZ in L. pneumophila; an additional strategy is likely utilized (46). One possible reason for this proposal is that the T4SS effector LpSpl may be used to inhibit LAP. Sphingosine1 phosphate lyase $(L p S p l)$ can decrease LC3 recruitment around L. pneumophila strains in macrophage cells (42).

\section{CONCLUSION, LIMITS, AND FUTURE DIRECTION}

From host side, the innate immunity and mucosal barriers play critical roles to maintain the autophagic responses $(51,52)$. From the bacterial side, effectors manipulate autophagy at different stages by using various strategies, including interfering with autophagy-initiating signaling, preventing the recognition of autophagy-involved proteins, subverting autophagy component homeostasis, manipulating the autophagy process (e.g., autophagosome maturation and autophagosome-lysosome fusion) and impacting other biological processes to affect autophagy. The research on effectors and autophagy has started to reveal basic features of autophagy manipulated by bacterial proteins for the benefit of bacterial survival and replication.

The progress in some field have shown better understanding of consequent host responses when autophagy is disturbed, such as killing host cells [SipB (25) and T3SS of Vibrio alginolyticus (28)], influencing host infection tolerance [Cig2 (40)], and escaping DC-mediated immune responses [ESAT-6 (41)]. Remarkably, bacteria could use multiple effectors (Salmonella and Legionella), and even two secretion systems (Vibrio parahaemolyticus), to mediate autophagy. Meanwhile, some effectors are versatile in manipulating autophagy (IcsB). Moreover, in the study of the effector $L p S p l$, the author found that the effector RavZ is not present in all strains of L. pneumophila, suggesting that this strain employs other effector, namely LpSpl (42), to inhibit autophagy. Therefore, determining whether one effector (even the partial function of one effector) is required for altering autophagic responses will help us to find novel effectors and better understanding of host-bacterial interactions.

The commonly used methods for exploring the effectors that are responsible for manipulating autophagy are: (a) deleting entire secretion systems or single genes and then analyzing the changes in autophagic responses in host cells infected with WT/mutant strains; (b) similarity searches to seek effectors that exhibit similar structures to host proteins, such as RavZ (35) and LpSpl (42); and (c) investigating effectors that can interact with autophagy-involved proteins and then exploring the underlying mechanisms, such as Ats-1 (36) and Etf-1 (6). Most of these studies were done in vitro and still lack in vivo models to verify the physiological relevance of the studies. We would like to advocate the organoid system to study the hostmicrobial interactions (53). In vivo, acute and chronic infectious models will help us to understand into the short-term and long-term effects of bacterial survival and suppressed autophagy. When studying the interaction between a target and autophagy, one single autophagy marker is not sufficient for determining changes in autophagic responses. Determining multiple related proteins in autophagy, having morphological observations, and monitoring autophagic flux will support more information for judgment and help us to differentiate autophagy from other biological process, like LAP (54).

Noteworthy, the studies on effectors-autophagy interactions in host cells is not only to determine the effectors, that can affect the host autophagic responses, and the underlying molecular mechanism. Some excellent researches are progressing in the direction for understanding autophagy and its regulators. Like the study of effector VopQ, VopQ can bind directly to the $\mathrm{V}$-ATPase $\mathrm{V}_{\mathrm{o}}$ domain, which appears to play a key role in the regulation of autophagy through amino acid sensing, and even more directly, autophagosome-lysosome membrane fusion. Though the details is unclear, this study enlighten us to further elucidate the role of V-ATPase in autophagosome fusion with the lysosome $(21,23)$. Additionally, $\mathrm{Xu}$ et al. recently found Salmonella effector SopF is a xenophagy-specific inhibitor. By determining the target of $s o p F$, they were able to identify the 
V-ATPase-ATG16L1 axis that mediates xenophagy initiation. Namely, upon infection, internalized bacteria cause damage to the residing vacuole, which is sensed by the vacuolar ATPase that then recruits ATG16L1 to initiate xenophagy. This study provides mechanistic insight into xenophagy recognition and initiation (15). It expands our knowledge to autophagic process, especially the crucial role of V-ATPase.

The causes of autophagy are numerous and complex. The mechanisms of effectors and autophagy have not been fully elucidated. Many important pathogenic Gram-negative bacteria still need to be tested. All the current studies focus on Gramnegative bacterial effectors, but Gram-positive and non-Gram stain bacterial effectors have been less attention (55). Moreover, the bacteria have abundant means/tools, not limited to effectors, to manipulate host autophagy. Most of these studies were focusing on uncovering the methods used by bacteria to inhibit autophagy, while ignoring the compensation of host cellular defense system. More studies are needed to understand the host cellular defense system in fighting back bacterial infection.

The physiological role of autophagy and its signaling mechanisms remain poorly understood. The study of interactions of bacterial effectors via pattern recognition receptors modulate the autophagy maybe uncover the underlying mechanisms. Overall, future directions could be focused on the following aspects in effectors-autophagy interactions to: (a) use various methods to determine multiple related proteins in autophagy, including morphological observations and monitoring autophagic flux to support accurate information about autophagic responses. Please refer to a comprehensive review of this subject (54); (b) understand the relationship

\section{REFERENCES}

1. Nakatogawa H, Suzuki K, Kamada Y, Ohsumi Y. Dynamics and diversity in autophagy mechanisms: lessons from yeast. Nat Rev Mol Cell Biol. (2009) 10:458-67. doi: 10.1038/nrm 2708

2. Mizushima N. Autophagy: process and function. Gene Dev. (2007) 21:286173. doi: $10.1101 / \operatorname{gad} .1599207$

3. Klionsky DJ, Cuervo AM, Dunn WA Jr, Levine B, van der Klei I, Seglen PO. How shall I eat thee? Autophagy. (2007) 3:413-6. doi: 10.4161/auto.4377

4. Desvaux M, Hebraud M, Talon R, Henderson IR. Secretion and subcellular localizations of bacterial proteins: a semantic awareness issue. Trends Microbiol. (2009) 17:139-45. doi: 10.1016/j.tim.2009.01.004

5. Hood RD, Singh P, Hsu F, Guvener T, Carl MA, Trinidad RR, et al. A type VI secretion system of Pseudomonas aeruginosa targets a toxin to bacteria. Cell Host Microbe. (2010) 7:25-37. doi: 10.1016/j.chom.2009.12.007

6. Lin M, Liu H, Xiong Q, Niu H, Cheng Z, Yamamoto A, et al. Ehrlichia secretes Etf-1 to induce autophagy and capture nutrients for its growth through RAB5 and class III phosphatidylinositol 3-kinase. Autophagy. (2016) 12:2145-66. doi: 10.1080/15548627.2016.1217369

7. Gong L, Cullinane M, Treerat P, Ramm G, Prescott M, Adler B, et al. The Burkholderia pseudomallei type III secretion system and BopA are required for evasion of LC3-associated phagocytosis. PLoS ONE. (2011) 6:e17852. doi: 10.1371/journal.pone.0017852

8. Flannagan RS, Cosio G, Grinstein S. Antimicrobial mechanisms of phagocytes and bacterial evasion strategies. Nat Rev Microbiol. (2009) 7:355-66. doi: $10.1038 / \mathrm{nrmicro} 2128$

9. Huang J, Brumell JH. Bacteria-autophagy interplay: a battle for survival. Nat Rev Microbiol. (2014) 12:101-14. doi: 10.1038/nrmicro3160 between autophagy and immunological responses, which will uncover the link between autophagy and life activity. Most researchers pay attention to the effect of effectors to autophagic responses and the underlying cellular and molecular mechanism, but less attention to the immunological consequences of these affects; (c) study diverse immune and inflammatory signals modulate autophagy in host cell through pattern recognition receptors, such as toll-like receptors and nucleotide-binding oligomerization domain (NOD)-like receptors (56-59).

Studies on effectors-autophagy interactions in host cells will provide new insights into the pathogenic mechanisms of infections and inflammation. A better understanding of the mechanisms used by bacterial effectors to manipulate autophagy will help the study of mechanisms in immunity, drug design, and novel therapeutic approaches for infectious diseases and chronic inflammation.

\section{AUTHOR CONTRIBUTIONS}

JS designed the theme and topic and obtained research funds. YJ drafted the manuscript and organized the figure and tables. YJ and JS finalized the manuscript.

\section{FUNDING}

We would like to acknowledge the UIC Cancer Center, the NIDDK/National Institutes of Health grant R01 DK105118, and R01DK114126 to JS. The study sponsors play no role in the study design, data collection, analysis, and interpretation of data.

10. Siqueira MDS, Ribeiro RM, Travassos LH. Autophagy and its interaction with intracellular bacterial pathogens. Front Immunol. (2018) 9:935. doi: 10.3389/fimmu.2018.00935

11. Baxt LA, Goldberg MB. Host and bacterial proteins that repress recruitment of LC3 to Shigella early during infection. PLoS ONE. (2014) 9:e94653. doi: 10.1371/journal.pone.0094653

12. Owen KA, Meyer CB, Bouton AH, Casanova JE. Activation of focal adhesion kinase by Salmonella suppresses autophagy via an Akt/mTOR signaling pathway and promotes bacterial survival in macrophages. PLoS Pathog. (2014) 10:e1004159. doi: 10.1371/journal.ppat.1004159

13. Popa C, Li L, Gil S, Tatjer L, Hashii K, Tabuchi M, et al. The effector AWR5 from the plant pathogen Ralstonia solanacearum is an inhibitor of the TOR signalling pathway. Sci Rep. (2016) 6:27058. doi: 10.1038/srep 27058

14. Feng ZZ, Jiang AJ, Mao AW, Feng Y, Wang W, Li J, et al. The Salmonella effectors SseF and SseG inhibit Rab1A-mediated autophagy to facilitate intracellular bacterial survival and replication. J Biol Chem. (2018) 293:966273. doi: 10.1074/jbc.M117.811737

15. Xu Y, Zhou P, Cheng S, Lu Q, Nowak K, Hopp AK, et al. A Bacterial effector reveals the V-ATPase-ATG16L1 axis that initiates xenophagy. Cell. (2019) 178:552-66.e20. doi: 10.1016/j.cell.2019.06.007

16. Jiao Y, Lin Z, Zhang Y-G, Lu R, Mei S, Pan Z, et al. Salmonella Enteritidis effector protein AvrA inhibits Beclin-1-dependent autophagy. Gastroenterology. (2017) 152:S200. doi: 10.1016/S0016-5085(17)30974-5

17. D'Cruze T, Gong L, Treerat P, Ramm G, Boyce JD, Prescott M, et al. Role for the Burkholderia pseudomallei type three secretion system cluster 1 bpscN gene in virulence. Infect Immun. (2011) 79:3659-64. doi: 10.1128/IAI.01351-10 
18. Ogawa M, Yoshimori T, Suzuki T, Sagara H, Mizushima N, Sasakawa C. Escape of intracellular Shigella from autophagy. Science. (2005) 307:727-31. doi: $10.1126 /$ science. 1106036

19. Noad J, von der Malsburg A, Pathe C, Michel MA, Komander D, Randow F. LUBAC-synthesized linear ubiquitin chains restrict cytosol-invading bacteria by activating autophagy and NF-кB. Nat Microbiol. (2017) 2:17063. doi: 10.1038/nmicrobiol.2017.63

20. Mesquita FS, Thomas M, Sachse M, Santos AJ, Figueira R, Holden DW. The Salmonella deubiquitinase SseL inhibits selective autophagy of cytosolic aggregates. PLoS Pathog. (2012) 8:e1002743. doi: 10.1371/journal.ppat.1002743

21. Sreelatha A, Bennett TL, Zheng H, Jiang QX, Orth K, Starai VJ. Vibrio effector protein, VopQ, forms a lysosomal gated channel that disrupts host ion homeostasis and autophagic flux. Proc Natl Acad Sci USA. (2013) 110:1155964. doi: 10.1073/pnas.1307032110

22. Burdette DL, Seemann J, Orth K. Vibrio VopQ induces PI3-kinaseindependent autophagy and antagonizes phagocytosis. Mol Microbiol. (2009) 73:639-49. doi: 10.1111/j.1365-2958.2009.06798.x

23. Sreelatha A, Orth K, Starai VJ. The pore-forming bacterial effector, VopQ, halts autophagic turnover. Autophagy. (2013) 9:2169-70. doi: 10.4161/auto.26449

24. Yu HB, Croxen MA, Marchiando AM, Ferreira RB, Cadwell K, Foster LJ, et al. Autophagy facilitates Salmonella replication in HeLa cells. MBio. (2014) 5:e00865-14. doi: 10.1128/mBio.00865-14

25. Hernandez LD, Pypaert M, Flavell RA, Galan JE. A Salmonella protein causes macrophage cell death by inducing autophagy. J Cell Biol. (2003) 163:1123-31. doi: $10.1083 /$ jcb.200309161

26. Kayath CA, Hussey S, El hajjami N, Nagra K, Philpott D, Allaoui A. Escape of intracellular Shigella from autophagy requires binding to cholesterol through the type III effector, IcsB. Microbes Infect. (2010) 12:956-66. doi: 10.1016/j.micinf.2010.06.006

27. Cullinane $\mathrm{M}$, Gong L, Li X, Lazar-Adler $\mathrm{N}$, Tra T, Wolvetang E, et al. Stimulation of autophagy suppresses the intracellular survival of Burkholderia pseudomallei in mammalian cell lines. Autophagy. (2008) 4:74453. doi: 10.4161/auto.6246

28. Zhao Z, Zhang L, Ren C, Zhao J, Chen C, Jiang X, et al. Autophagy is induced by the type III secretion system of Vibrio alginolyticus in several mammalian cell lines. Arch Microbiol. (2011) 193:53-61. doi: 10.1007/s00203-010-0646-9

29. De La Rosa I, Eissa NT, Xu Y. Negative regulation of autophagy by Pseudomonas aeruginosa type 3 secretion system in airway epithelial cells. Am J Respir Crit Care Med. (2013) 187:A4554. Available online at: https://www.atsjournals.org/doi/abs/10.1164/ajrccm-conference.2013.187. 1_MeetingAbstracts.A4554

30. Deuretzbacher A, Czymmeck N, Reimer R, Trulzsch K, Gaus K, Hohenberg $\mathrm{H}$, et al. $\beta 1$ integrin-dependent engulfment of Yersinia enterocolitica by macrophages is coupled to the activation of autophagy and suppressed by type III protein secretion. J Immun. (2009) 183:5847-60. doi: 10.4049/jimmunol.0804242

31. Ye Z, Petrof EO, Boone D, Claud EC, Sun J. Salmonella effector AvrA regulation of colonic epithelial cell inflammation by deubiquitination. Am J Pathol. (2007) 171:882-92. doi: 10.2353/ajpath.2007.070220

32. Lin Z, Zhang YG, Xia Y, Xu X, Jiao X, Sun J. Salmonella enteritidis effector AvrA stabilizes intestinal tight junctions via the JNK pathway. J Biol Chem. (2016) 291:26837-49. doi: 10.1074/jbc.M116.757393

33. Huang J, Birmingham CL, Shahnazari S, Shiu J, Zheng YT, Smith AC, et al. Antibacterial autophagy occurs at PI(3)P-enriched domains of the endoplasmic reticulum and requires Rab1 GTPase. Autophagy. (2011) 7:1726. doi: 10.4161/auto.7.1.13840

34. Choy A, Dancourt J, Mugo B, O'Connor TJ, Isberg RR, Melia TJ, et al. The Legionella effector RavZ inhibits host autophagy through irreversible Atg8 deconjugation. Science. (2012) 338:1072-6. doi: 10.1126/science.1227026

35. Yang A, Pantoom S, Wu YW. Elucidation of the anti-autophagy mechanism of the Legionella effector RavZ using semisynthetic LC3 proteins. Elife. (2017) 6:e23905. doi: 10.7554/eLife.23905

36. Niu H, Xiong Q, Yamamoto A, Hayashi-Nishino M, Rikihisa Y. Autophagosomes induced by a bacterial Beclin-1 binding protein facilitate obligatory intracellular infection. Proc Natl Acad Sci USA. (2012) 109:20800-7. doi: $10.1073 /$ pnas.1218674109
37. Yu Y, Fang L, Zhang Y, Sheng H, Fang W. VgrG2 of type VI secretion system 2 of Vibrio parahaemolyticus induces autophagy in macrophages. Front Microbiol. (2015) 6:168. doi: 10.3389/fmicb.2015.00168

38. Wang C, Fu J, Wang M, Cai Y, Hua X, Du Y, et al. Bartonella quintana type IV secretion effector BepE-induced selective autophagy by conjugation with K63 polyubiquitin chain. Cell Microbiol. (2019) 21:e12984. doi: 10.1111/cmi.12984

39. Joshi AD, Swanson MS. Secrets of a successful pathogen: Legionella resistance to progression along the autophagic pathway. Front Microbiol. (2011) 2:138. doi: $10.3389 /$ fmicb. 2011.00138

40. Kohler LJ, Reed Sh C, Sarraf SA, Arteaga DD, Newton HJ, Roy CR. Effector protein Cig2 decreases host tolerance of infection by directing constitutive fusion of autophagosomes with the Coxiella-containing vacuole. MBio. (2016) 7:e01127-16. doi: 10.1128/mBio.01127-16

41. Romagnoli A, Etna MP, Giacomini E, Pardini M, Remoli ME, Corazzari M, et al. ESX-1 dependent impairment of autophagic flux by Mycobacterium tuberculosis in human dendritic cells. Autophagy. (2012) 8:1357-70. doi: $10.4161 /$ auto.20881

42. Rolando M, Escoll P, Nora T, Botti J, Boitez V, Bedia C, et al. Legionella pneumophila S1P-lyase targets host sphingolipid metabolism and restrains autophagy. Proc Natl Acad Sci USA. (2016) 113:1901-6. doi: 10.1073/pnas.1522067113

43. Jiang F, Wang X, Wang B, Chen L, Zhao Z, Waterfield NR, et al. The Pseudomonas aeruginosa type VI secretion PGAP1-like effector induces host autophagy by activating endoplasmic reticulum stress. Cell Rep. (2016) 16:1502-9. doi: 10.1016/j.celrep.2016.07.012

44. Zhang J, Li M, Li Z, Shi J, Zhang Y, Deng X, et al. Deletion of the type IV secretion system effector VceA promotes autophagy and inhibits apoptosis in Brucella-infected human trophoblast cells. Curr Microbiol. (2019) 76:510-9. doi: 10.1007/s00284-019-01651-6

45. Martinez J, Malireddi RK, Lu Q, Cunha LD, Pelletier S, Gingras S, et al. Molecular characterization of LC3-associated phagocytosis reveals distinct roles for Rubicon, NOX2 and autophagy proteins. Nat Cell Biol. (2015) 17:893-906. doi: 10.1038/ncb3192

46. Hubber A, Kubori T, Coban C, Matsuzawa T, Ogawa M, Kawabata T, et al. Bacterial secretion system skews the fate of Legionella-containing vacuoles towards LC3-associated phagocytosis. Sci Rep. (2017) 7:44795. doi: $10.1038 /$ srep44795

47. Chen ML, Yi L, Jin X, Liang XY, Zhou Y, Zhang T, et al. Resveratrol attenuates vascular endothelial inflammation by inducing autophagy through the cAMP signaling pathway. Autophagy. (2013) 9:2033-45. doi: 10.4161/auto. 26336

48. Howe D, Melnicakova J, Barak I, Heinzen RA. Fusogenicity of the Coxiella burnetii parasitophorous vacuole. Ann NY Acad Sci. (2003) 990:556-62. doi: 10.1111/j.1749-6632.2003.tb07426.x

49. Russell AB, LeRoux M, Hathazi K, Agnello DM, Ishikawa T, Wiggins PA, et al. Diverse type VI secretion phospholipases are functionally plastic antibacterial effectors. Nature. (2013) 496:508-12. doi: 10.1038/nature12074

50. Yorimitsu T, Nair U, Yang Z, Klionsky DJ. Endoplasmic reticulum stress triggers autophagy. J Biol Chem. (2006) 281:30299-304. doi: 10.1074/jbc.M607007200

51. Wu S, Zhang YG, Lu R, Xia Y, Zhou D, Petrof EO, et al. Intestinal epithelial vitamin D receptor deletion leads to defective autophagy in colitis. Gut. (2015) 64:1082-94. doi: 10.1136/gutjnl-2014-307436

52. Sun J. VDR/vitamin D receptor regulates autophagic activity through ATG16L1. Autophagy. (2016) 12:1057-8. doi: 10.1080/15548627.2015.1072670

53. Zhang YG, Zhu X, Lu R, Messer JS, Xia Y, Chang EB, et al. Intestinal epithelial HMGB1 inhibits bacterial infection via STAT3 regulation of autophagy. Autophagy. (2019) 15:1935-53. doi: 10.1080/15548627.2019.1596485

54. Klionsky DJ, Abdelmohsen K, Abe A, Abedin MJ, Abeliovich H, Acevedo Arozena A, et al. Guidelines for the use and interpretation of assays for monitoring autophagy (3rd edition). Autophagy. (2016) 12:1-222. doi: 10.1080/15548627.2015.1100356

55. Simeone R, Bottai D, Brosch R. ESX/type VII secretion systems and their role in host-pathogen interaction. Curr Opin Microbiol. (2009) 12:4-10. doi: 10.1016/j.mib.2008.11.003

56. Takahama M, Akira S, Saitoh T. Autophagy limits activation of the inflammasomes. Immunol Rev. (2018) 281:62-73. doi: 10.1111/imr.12613 
57. Lee JW, Nam H, Kim LE, Jeon Y, Min H, Ha S, et al. TLR4 (toll-like receptor 4) activation suppresses autophagy through inhibition of FOXO3 and impairs phagocytic capacity of microglia. Autophagy. (2019) 15:753-70. doi: 10.1080/15548627.2018.1556946

58. Li J, Li B, Cheng Y, Meng Q, Wei L, Li W, et al. The synergistic effect of NOD2 and TLR4 on the activation of autophagy in human submandibular gland inflammation. J Oral Pathol Med. (2019) 48:87-95. doi: 10.1111/jop.12793

59. Li C, Ma L, Liu Y, Li Z, Wang Q, Chen Z, et al. TLR2 promotes development and progression of human glioma via enhancing autophagy. Gene. (2019) 700:52-9. doi: 10.1016/j.gene.2019.02.084
Conflict of Interest: The authors declare that the research was conducted in the absence of any commercial or financial relationships that could be construed as a potential conflict of interest.

Copyright (C) 2019 Jiao and Sun. This is an open-access article distributed under the terms of the Creative Commons Attribution License (CC BY). The use, distribution or reproduction in other forums is permitted, provided the original author $(s)$ and the copyright owner(s) are credited and that the original publication in this journal is cited, in accordance with accepted academic practice. No use, distribution or reproduction is permitted which does not comply with these terms. 